JURNAL ILMIAH KOMPUTER GRAFIS, Vol.14, No.2, Desember 2021, pp. 138 - 147

p-ISSN : 1979-0414(print)

e-ISSN : 2621-6256 (online)

http://journal.stekom.ac.id/index.php/pixel

- page 138

\title{
PENINGKATAN KETERAMPILAN MEMBACA INTENSIF DENGAN MENGGUNAKAN PEMBELAJARAN KOOPERATIF STRATEGI KWL PADA SISWA KELAS III SDN KALIWUNGU 1 KECAMATAN KALIWUNGU KABUPATEN SEMARANG
}

\author{
Suparpti Suprapti ${ }^{1}$, Hendri Rasminto ${ }^{2}$ \\ ${ }^{1}$ Desain Grafis - Universitas STEKOM, suprapti@stekom.ac.id \\ ${ }^{2}$ Desain Grafis - Universitas STEKOM, hendriR@gmail.com \\ J1. Majapahit 605, Semarang, telp/fax : 024-6717201-02
}

\section{ARTICLE INFO}

Article history:

Received 30 September 2021

Received in revised form 2 Oktober 2021

Accepted 10 November 2021

Available online 1 Desember 2021

\section{ABSTRACT}

This study used a classroom action research design which was carried out in three stages, namely the pre-cycle stage, cycle I, and cycle II with the research subjects being grade III students at SDN Kaliwungu 1. This study used two variables, namely intensive reading skills and intensive reading learning using the KWL strategy. . Pre-cycle data collection was done by using the test technique, while in the first cycle and the second cycle using the test and non-test technique. Non-test instruments in the form of observations, journals, interviews, and documentation. Data analysis includes quantitative and qualitative data.

The results showed that after participating in intensive reading learning using the KWL strategy, the average value of intensive reading skills of third grade students at SDN Kaliwungu 1 increased. The average value of intensive reading using the KWL strategy achieved by students in the pre-cycle was 56 and in the first cycle it increased to 65 or $9 \%$ then in the second cycle it increased to 76 or $11 \%$. Changes in attitudes and behavior of third grade students at SDN Kaliwungu 1 Kaliwungu District, Semarang Regency have increased towards a better direction, namely students are more active and enthusiastic in learning, because students are starting to enjoy and enjoy intensive reading learning using the KWL strategy.

Keywords: Intensive reading, cooperative learning, and resident KWL strategies

\section{Pendahuluan}

Perkembangan ilmu pengetahuan dan teknologi menuntut terciptanya masyarakat yang gemar belajar. Proses belajar efektif antara lain dilakukan melalui membaca. Masyarakat yang gemar membaca memperoleh pengetahuan dan wawasan baru yang akan semakin meningkatkan kecerdasannya sehingga mereka lebih mampu menjawab tantangan hidup pada masa-masa mendatang.

Received September 23, 2021; Revised Oktober 10, 2021; Accepted November 17, 2021 
p-ISSN : 1979-0414 e-ISSN : 2621-6256

Membaca adalah suatu kegiatan yang banyak dilakukan siswa dalam belajar. Kegiatan ini mulai dilakukan anak ketika masuk sekolah dasar sampai sekolah lanjutan tingkat pertama, bahkan sampai tingkat perguruan tinggi (pendidikan formal). Membaca merupakan salah satu dari tiga kemampuan dasar (membaca, menulis, berhitung) yang harus dimiliki oleh pelajar jika ingin berhasil mengakses informasi saat mengembangkan ilmu pengetahuan di bangku sekolah mereka. Aktivitas membaca akan menjadi hobi atau kegemaran jika pembaca dapat membaca manfaat bagi pelakunya.

Walaupun informasi bisa ditemukan dari media lain seperti televisi dan radio, namun peran membaca tak dapat digantikan sepenuhnya. Membaca tetap memegang peranan penting dalam kehidupan sehari-hari karena tidak semua informasi bisa didapatkan dari media televis dan radio.

Membaca adalah interaktif. Keterlibatan pembaca dengan teks tergantung pada konteks. Orang yang senang membaca suatu teks yang bermanfaat, akan menemui beberapa tujuan yang ingin dicapainya, teks yang dibaca seseorang harus mudah dipahami (readable) sehingga terjadi interaksi antara pembaca dan teks. Membaca juga merupakan suatu strategis pembaca yang efektif menggunakan berbagai strategi membaca yang sesuai dengan teks dan konteks dalam rangka mengonstruk makna ketika membaca. Strategi ini bervariasi sesuai dengan jenis teks dan tujuan membaca.

Membaca semakin penting dalam kehidupan masyarakat yang makin kompleks. Setiap aspek kehidupan melibatkan kegiatan membaca. Tanda-tanda jalan mengarahkan orang yang berpergian sampai pada tujuannya, menginformasikan pengemudi mengenai bahaya di jalan, dan mengingatkan aturan-aturan lalu lintas. Pengusaha catering tidak perlu harus pergi ke pasar untuk mengetahui harga bahan-bahan yang akan dibutuhkan. Dia cukup membaca surat kabar untuk mendapatkan informasi tersebut. Kemudian, dia bisa merencanakan apa saja yang harus dibelinya disesuaikan dengan informasi tentang bahan-bahan yang dibutuhkannya.

Di samping itu, keterampilan membaca merupakan tuntutan realitas kehidupan sehari-hari manusia. Beribu judul buku dan berjuta koran diterbitkan setiap hari. Ledakan informasi ini menimbulkan tekanan guru untuk menyiapkan bacaan yang memuat informasi yang relevan untuk siswa-siswanya. Walaupun tidak semua informasi perlu dibaca, tetapi jenis-jenis bacaan tertentu perlu dibaca.

Tujuan utama membaca adalah mendapatkan informasi dari bacaan yang dibaca. Untuk mendapatkan informasi, pembaca perlu membuat atau mengikuti sistem atau cara kerja dalam membaca. Sistem kerja yang dibuat meliputi cara kerja fisik dan psikis. Cara kerja fisik berkaitan dengan bagaimana mata membaca atau memandang bacaan yang merupakan sistem grafis. Sistem kerja psikis berkaitan dengan bagaimana cara kerja otak memahami bacaan. Gabungan cara kerja fisik dan psikis merupakan proses dalam membaca karena membaca dimulai dari proses visual (mata) dan diakhiri pada proses yang terdapat di otak, yaitu memahami atau mengkritis bacaan. Sistem atau cara kerja, baik fisik maupun psikis, dalam memahami bacaan dinamakan model membaca.

Berdasarkan pengamatan peneliti selama ini minat baca di kalangan siswa khususnya pada siswa SD sangat rendah itu dikarenakan mereka lebih suka bermain-main dari pada belajar, selain itu juga karena pantauan dari orang tua yang kurang, sehingga dapat mempengaruhi dalam proses pembelajaran.

Diduga, penyebab kurangnya kemampuan membaca pada siswa kelas III SDN Kaliwungu 1 sebagai berikut : (1) rendahnya minat maupun motivasi siswa belajar bahasa Indonesia. Hal ini dapat dilihat dengan sulitnya siswa memahami suatu bacaan sehingga tugas-tugas yang berkenaan dengan kegiatan membaca dalam pelajaran bahasa Indonesia terabaikan; (2) terdapatnya bacaan atau kata-kata asing yang tidak sesuai dengan di kalangan mereka, ada juga bahan bacaan yang terlalu panjang dan kurang variatif sehingga bacaan tersebut tidak menarik perhatian siswa; dan (3) metode pembelajaran yang kurang bervariasi sehingga siswa merasa bosan.

Peran guru amatlah menentukan dalam mengajarkan bahasa Indonesia. Oleh karena itu, guru dituntut untuk menguasai bahasa Indonesia dan pembelajarannya. Begitu juga bahasa Indonesia semestinya menjadi mata pelajaran yang menarik bagi siswanya. Kemenarikan itu pada 
p-ISSN: 1979-0155e-ISSN : 1907-0012

akhirnya membawa siswa ke tingkat komunikasi yang lancar. Komunikasi yang didasari oleh minat yang kuat dari siswa. Guru berperan besar dalam hal itu. Peran tersebut didasari oleh kekuatan konsep dan kekuatan mengembangkan strategi pembelajaran. Agar siswa terhindar dari permasalahan tersebut guru bahasa Indonesia hendaknya menerapkan strategi membaca yang sesuai dengan situasi dan kondisi siswa. Salah satu upaya yang dapat dilakukan adalah dengan menggunakan pembelajaran membaca intensif dengan pembelajaran kooperatif strategi KWL

\section{TINJAUAN PUSTAKA}

Penelitian yang dilakukan oleh para mahasiswa dalam penyusunan skripsi. Skripsi yang berjudul Peningkatan Kemampuan Membaca Intensif Teks Profil Tokoh dengan Pendekatan Kontekstual Komponen Inquiry pada Siswa Kelas VIIB SMPN 10 Semarang Tahun Ajaran 2005 / 2006 oleh Munawaroh menjelaskan bahwa terjadi peningkatan keterampilan membaca intensif teks profil tokoh dengan pendekatan kontekstual komponen inquiry dengan bukti skor rata-rata kelas pada pratindakan sebesar 56,51 atau berada pada kategori kurang. Pada siklus I rata-rata skor sebesar 10,95\% menjadi 67,46 berada pada kategori cukup. Pada siklus II rata-rata kelas menjadi 81. hal ini berarti terjadi peningkatan dari siklus I ke siklus II sebesar 13,54\%.

Persamaan yang dilakukan oleh Munawaroh dengan penelitian yang akan dilakukan terletak pada desain penelitian, instrumen, dan analisis data. Masalah yang dikaji dalam penelitian Munawaroh adalah bagaimana peningkatan kemampuan membaca intensif teks profil tokoh dan bagaimana perubahan tingkah laku siswa setelah melakukan pembelajaran membaca intensif dengan pendekatan kontekstual komponen inquiry. Tujuan penelitian ini adalah untuk meningkatkan keterampilan membaca intensif teks profil tokoh dan bagaimana perubahan tingkah laku siswa setelah melakukan pembelajaran membaca intensif dengan pendekatan kontekstual komponen inquiry. Subjek penelitiannya adalah siswa kelas VIIB SMPN 10 Semarang.[1]

Penelitian yang dilakukan peneliti memiliki beberapa perbedaan dengan penelitian yang dilakukan oleh Munawaroh antara lain masalah yang dikaji peneliti adalah bagaimana peningkatan keterampilan membaca intensif dan bagaimana perubahan tingkah laku siswa setelah dilakukan pembelajaran membaca intensif menggunakan pembelajaran kooperatif strategi KWL. Tujuan penelitian ini adalah untuk meningkatkan keterampilan membaca intensif pada siswa untuk mengetahui perubahan tingkah laku siswa setelah dilakukan proses pembelajaran dengan pembelajaran kooperatif strategi KWL. Variabel penelitian ini adalah variabel pembelajaran membaca intensif menggunakan strategi KWL dalam pembelajaran kooperatif. Subjek penelitiannya adalah siswa kelas III SDN Kaliwungu 1 Kecamatan Sayung, Kabupaten Demak .

Roklimawati dalam skripsinya yang berjudul Peningkatan Keterampilan Membaca Intensif dengan Pendekatan Kontekstual Komponen Inquiry pada Siswa Kelas VIIF SMPN 37 Semarang hasil penelitian menunjukkan ada peningkatan keterampilan membaca intensif pada siklus II setelah diadakan penelitian dengan pendekatan kontekstual. Rata-rata kelas diperoleh sebesar 57,39 Pada siklus I, siswa yang mendapat nilai rata-rata minimal 7,51 meningkat sebesar 22,86\% sedangkan siklus II nilai rata-rata minimal 7,51 meningkat sebesar11,43\%. Siklus II meningkat sebesar $11,43 \%$ sedangkan siklus I meningkat menjadi 78,57. Jadi peningkatan siklus II 36,90\%. [2]

Persamaan penelitian yang dilakukan oleh Roklimawati dengan penelitian yang akan dilakukan terletak pada desain penelitian, instrumen, dan analisis data. Desain penelitian yang digunakan sama-sama penelitian tindakan kelas, instrumen yang digunakan berupa instumen tes dan nontes, sedangkan analisis data meliputi observasi, jurnal, wawancara dan dokumentasi. Perbedaan penelitian Roklimawati dengan penelitian penulis terletak pada masalah yang dikaji, tujuan penelitian, tindakan yang akan dilakukan, variabel penelitian dan subjek penelitian. Masalah yang dikaji dalam Roklimawati adalah bagaimana peningkatan keterampilan membaca intensif dan bagaimana perubahan tingkah laku siswa setelah melakukan pembelajaran membaca intensif dengan pendekatan kontekstual komponen inquiry. Variabel penelitian ini adalah variabel

JURNAL ILMIAH KOMPUTER GRAFIS Vol. 14, No. 2, Desember 2021 : 138 - 147 
p-ISSN : 1979-0414 e-ISSN : 2621-6256

membaca intensif dengan pendekatan kontekstual komponen inquiry. Subjek penelitiannya adalah siswa kelas VIIF SMPN 37 Semarang.

Penelitian tentang membaca intensif juga dilakukan oleh Innasiah dalam penelitian yang berjudul Peningkatan Keterampilan Membaca Intensif Teks Berita dengan Pendekatan Kontekstual Komponen Inquiry pada Siswa Kelas VIIE MTs. Negeri Salatiga Tahun Ajaran 2005/2006 menunjukkan adanya peningkatan keterampilan membaca intensif teks berita siswa kelas VIIE MTs. Negeri Salatiga setelah mengikuti pembelajaran dengan menggunakan pendekatan kontekstual komponen inquiry. Hal ini dibuktikan dengan meningkatnya hasil analisis data dari data tes pratindakan, siklus I dan siklus II. Hasil tes tindakan yaitu sebelum tindakan penelitian dilakukan, menunjukkan bahwa rata-rata yang dicapai sebesar 58,76 atau sebesar $58,76 \%$. Pada siklus I rata-rata skor yang dicapai sebesar 71,88 atau sebesar 71,88\%, pada siklus ini terjadi peningkatan sebesar $13,12 \%$ dari tes pratindakan. Pada siklus II rata-rata skor meningkat menjadi 81,90 atau sebesar $12,02 \%$ dari siklus I. Perilaku siswa krlas VIIIE MTs. Negeri Salatiga setelah mengikuti pembelajaran membaca intensif teks berita dengan pendekatan kontekstual komponen inquiry juga mengalami perubahan. Perubahan tingkah laku siswa terlihat secara jelas saat proses pembelajaran. [3]

Persamaan penelitian Innasiah dengan penelitian ini teletak pada desain penelitian, intrumen yang digunakan, dan analisis data. Desain penelitian yang digunakan sama-sama penelitian tindakan kelas, instrumen yang digunakan berupa instrumen tes dan nontes. Analisis data nontes melalui deskriptif kualitatif sedangkan data tes berupa deskripsi presentasi. Perbedaan penelitian yang dilakukan oleh Innasiah dengan penelitian yang akan dilakukan adalah pada masalah yang dikaji, tujuan penelitian, dan subjek penelitian. Masalah yang dikaji dalam penelitian Innasiah adalah bagaimanakah peningkatan keterampilan membaca intensif teks berita dan bagaimanakah perubahan tingkah laku siswa kelas VIIIE MTs. Negeri Salatiga setelah melakukan pembelajaran membaca intensif teks berita dengan menggunakan pendekatan kontekstual komponen inquiry. Tujuan penelitian ini adalah untuk meningkatkan keterampilan membaca intensif teks berita dan untuk mengetahui perubahan perilaku siswa terhadappembelajaran membaca intensif teks berita dengan menggunakan pendekatan kontekstual komponen inquiry. Variabel penelitian adalah variabel keterampilan membaca intensif teks berita dan variabel pendekatan kontekstual ini adalah siswa kelas VIIIE MTs. Negeri Salatiga.

Penelitian yang dilakukan peneliti memiliki beberapa perbedaan dengan penelitian yang dilakukan oleh Innasiah antara lain, masalah yang dikaji peneliti adalah bagaimana peningkatan keterampilan membaca intensif dan bagaimana perubahan tingkah laku siswa setelah dilakukan pembelajaran membaca intensif dalam pembelajaran kooperatif menggunakan strategi KWL. Tujuan penelitian ini adalah untuk meningkatkan keterampilan membaca intensif pada siswa dan untuk mengetahui perubahan tingkah laku siswa setelah dilakukan proses pembelajaran kooperatif strategi KWL. Variabel penelitian ini adalah variabel pembelajaran membaca intensif dengan menggunakan pembelajaran kooperatif strategi KWL siswa kelas III SDN Kaliwungu 1 Kecamatan Kaliwungu, Kab Semarang.

Skripsi yang berjudul Peningkatan Keterampilan Membaca Intensif Teks Berita dengan Strategi Metakognitif pada Siswa kelas VIIC SMP Teuku Umar Semarang Tahun Ajaran 2006 / 2007 oleh Lestari pada siklus I dan siklus II mengalami peningkatan sebesar 13,3\% 74 berkategori baik. Nilai rata-rata teks membaca intensif teks berita pada prasiklus sebesar 55,2 termasuk dalam kategori cukup baik, siklus I rata-rata mencapai 61,8 dengan kategori cukup baik sehingga ada peningkatan sebesar $6,6 \%$ dari hasil prasiklus. Pada siklus II nilai rata-rata mencapai 74 , terjadi peningkatan sebesar $19,7 \%$ dari hasil prasiklus peningkatan nilai rata-rata pada siklus II juga di ikuti dengan perubahan perilaku tidak baik menjadi baik. Pada siklus II siswa lebih tertarik dan merasa senang dengan pembelajaran membaca intensif teks berita.

Persamaan penelitian Lestari dengan penelitian ini terletak pada desain penelitian, instrumen yang digunakan, dan analisis data. Desain penelitian yang digunakan sama-sama penelitian tindakan kelas, instrumen yang digunakan berupa instrumen tes dan nontes. Analisis data nontes melalui deskriptif kualitatif sedangkan data tes berupa deskripsi presentasi. Perbedaan 
p-ISSN: 1979-0155e-ISSN : 1907-0012

penelitian yang dilakukan oleh Lestari dengan penelitian yang akan dilakukan adalah pada masalah yang dikaji, tujuan penelitian, dan subjek penelitian. Masalah yang dikaji dalam penelitian Lestari adalah bagaimanakah peningkatan keterampilan membaca intensif teks berita dan bagaimanakah perubahan tingkah laku siswa kelas VIIC SMP Teuku Umar Semarang setelah melakukan pembelajaran membaca intensif teks berita dengan menggunakan strategi metakognitif. Tujuan penelitian ini adalah untuk meningkatkan keterampilan membaca intensif teks berita dan untuk mengetahui perubahan perilaku siswa terhadap pembelajaran membaca intensif teks berita dengan menggunakan strategi metakognitif. Variabel penelitian adalah variabel keterampilan membaca intensif teks berita dan variabel penelitian ini adalah siswa kelas VIIC SMP Teuku Umar Semarang.

Penelitian Pitayani yang berjudul Peningkatan Keterampilan Membaca Intensif Grafik melalui Permainan Kuis Tim pada Siswa Kelas IXB MTs Nurul Ulum Mranggen Demak Tahun Ajaran 2006/2007 menunjukkan adanya peningkatan keterampilan membaca intensif grafik melalui permainan kuis tim. Peningkatan ini dapat dilihat berdasarkan hasil tes yang dilakukan pada siswa kelas IXB MTs Nurul Ulum Mranggen Demak. Meliputi tes awal (prasiklus), tes akhir siklus I dan tes akhir siklus II. Hasil tes awal yaitu hasil tes sebelum tindakan penelitian kelas dilakukan, menunjukkan bahwa nilai rata-rata kelas sebesar 61 dan siklus I meningkat menjadi 71 atau sebesar $10 \%$ kemudian pada siklus II meningkat menjadi 79 atau sebesar $8 \%$. Perubahan sikap dan perilaku siswa kelas IXB MTs. Nurul Ulum Demak mengalami peningkatan kea rah yang lebih baik pada saat mengikuti pembelajaran membaca intensif grafik melalui permainan kuis tim yaitu siswa yang mulanya tidak terfokus menjadi terfokus dalam membaca grafik.[5]

Persamaan penelitian Pitayani dengan penelitian ini terletak pada desain penelitian, instrumen yang digunakan, dan analisis data. Desain penelitian yang digunakan sama-sama penelitian tindakan kelas, instrumen yang digunakan berupa instrumen tes dan nontes. Analisis data nontes melalui deskriptif kualitatif sedangkan data tes berupa deskripsi presentasi. Perbedaan penelitian yang dilakukan oleh Pitayani dengan penelitian yang akan dilakukan adalah pada masalah yang dikaji, tujuan penelitian, dan subjek penelitian. Masalah yang dikaji dalam penelitian Pitayani adalah bagaimanakah peningkatan keterampilan membaca intensif grafik dan bagaimanakah perubahan tingkah laku siswa kelas IXB MTs Nurul Ulum Mranggen Demak setelah melakukan pembelajaran membaca intensif grafik melalui permainan kuis tim. Tujuan penelitian ini adalah untuk meningkatkan keterampilan membaca intensif grafik dan untuk mengetahui perubahan perilaku siswa terhadap pembelajaran membaca intensif grafik melalui permainan kuis tim. Variabel penelitian adalah variabel keterampilan membaca intensif grafik dan variabel penelitian ini adalah siswa kelas IXB MTs Nurul Ulum Mranggen Demak

Penelitian yang dilakukan peneliti memiliki beberapa perbedaan dengan penelitian yang dilakukan oleh Pitayani antara lain, masalah yang dikaji peneliti adalah bagaimana peningkatan keterampilan membaca intensif dan bagaimana perubahan tingkah laku siswa setelah dilakukan pembelajaran membaca intensif dalam pembelajaran kooperatif menggunakan strategi KWL. Tujuan penelitian ini adalah untuk meningkatkan keterampilan membaca intensif pada siswa dan untuk mengetahui perubahan tingkah laku siswa setelah dilakukan proses pembelajaran kooperatif strategi KWL. Variabel penelitian ini adalah variabel pembelajaran membaca intensif dengan menggunakan pembelajaran kooperatif strategi KWL siswa kelas III SDN Kaliwungu 1 Kecamatan Kaliwungu, Kab Semarang.

Berdasarkan kajian pustaka tersebut, dapat diketahui bahwa penelitian tindakan kelas tentang membaca membaca intensif memiliki persamaan, yaitu kemampuan siswa relatif rendah, perlu adanya peningkatan keterampilan membaca intensif bagi siswa dan percobaan penggunaan metode atau teknik dan pendekatan pembelajaran. Selain itu kita juga dapat mengatahui bahwa penelitian tentang membaca sangat menarik dan banyak dilakukan oleh peneliti-peneliti lain. Namun dalam pelaksanaannya setiap peneliti menggunakan metode yang beraneka ragam dalam meningkatkan keterampilan membaca siswa. Selain itu, masing-masing peneliti juga harus

JURNAL ILMIAH KOMPUTER GRAFIS Vol. 14, No. 2, Desember 2021 : 138 - 147 
p-ISSN : 1979-0414 e-ISSN : 2621-6256

memiliki hal-hal yang baru yang tidak sama dengan penelitian lainnya, begitu juga dengan penelitian kali ini.

Hodgson [6] membaca adalah suatu proses yang dilakukan serta dipergunakan oleh pembaca untuk memperoleh pesan yang hendak disampaikan oleh penulis melalui media katakata / bahasa tulis. Suatu proses yang menuntut agar kelompok kata yang merupakan suatu kesatuan akan terlihat dalam suatu pandangan sekilas, dan agar makna kata-kata secara individual akan dapat diketahui. Kalau hal ini tidak terpenuhi, maka pesan yang tersurat dan yang tersirat tidak akan tertangkap atau dipahami, dan proses membaca itu tidak terlaksana dengan baik.

Anderson berpendapat membaca merupakan suatu proses penyandian kembali dan pembacaan sandi (a recording and decoding process), berlainan dengan berbicara dan menulis yang justru melibatkan penyandian (encoding). Sebuah aspek pembacaan sandi (decoding) adalah menghubungkan kata-kata tulis (written word) dengan makna bahasa lisan (oral language meaning) yang mencakup pengubahan tulisan / cetakan menjadi bunyi yang bermakna.

Rahim, [7] mengemukakan bahwa definisi membaca mencakup (1) membaca merupakan suatu proses, (2) membaca adalah strategis, dan (3) membaca merupakan interaktif. Membaca merupakan suatu proses dimaksudkan informasi dari teks dan pengetahuan yang dimiliki oleh pembaca mempunyai peranan yang utama dalam membentuk makna. Menurut Tarigan [6] membaca dapat pula dianggap sebagai suatu proses untuk memahami yang tersirat dalam yang tersurat, melihat pikiran yang terkandung di dalam kata-kata yang tertulis.

Pembelajaran kooperatif adalah khas di antara model-model pembelajaran karena menggunakan suatu struktur tugas dan penghargaan yang berbeda untuk meningkatkan pembelajaran siswa. Struktur tugas memaksa siswa untuk bekerja sama dalam kelompok kecil. Sistem penghargaan mengakui usaha bersama, sama baiknya seperti usaha individual. Model pembelajaran kooperatif berkembang dari kebiasaan pendidikan yang menekankan pada pemikiran demokratis dan latihan atau praktek, dan pembelajaran aktif [8].

\section{METODE PENELITIAN}

Penelitian ini merupakan Penelitian Tindakan Kelas (PTK), artinya bentuk yang dilakukan secara kolaboratif dan partisipatif. Penelitian tindakan kelas cukup potensial untuk membantu memecahkan masalah guru dalam menjalankan profesinya, sekaligus meningkatkan kinerjanya. Penelitian tindakan kelas (PTK) ini bertujuan untuk memperbaiki pelaksanaan pembelajaran. Dengan PTK diharapkan kualitas pembelajaran menjadi lebih baik. Secara visual, penelitian tindakan kelas dapat digambarkan sebagai berikut:

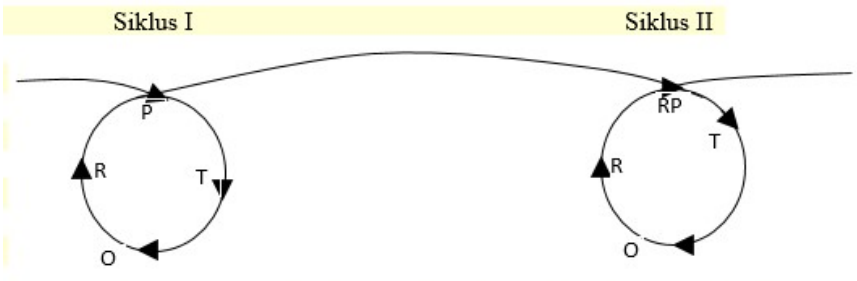

Gambar 1. Desain penelitian Tindakan Kelas Siklus I dan Siklus II (Tim Pelatihan Proyek GSM

1999:6)

$$
\begin{aligned}
& \text { Keterangan : } \\
& \mathrm{O} \quad \text { : Observasi } \\
& \mathrm{P} \quad \text { : Perencanaan } \\
& \mathrm{R}: \text { Refleksi } \\
& \mathrm{T} \text { : Tindakan } \\
& \mathrm{RP}: \text { Revisi Perencanaan }
\end{aligned}
$$

Observasi awal dilakukan sebelum peneliti melakukan siklus I dan siklus II. Observasi awal ini dilakukan agar peneliti mengetahui kondisi siswa dalam kelas, dan kesulitan yang dialami oleh siswa. Selain itu juga observasi awal bertujuan agar siswa mengenal peneliti sehingga pada saat penelitian siswa sudah terbiasa dan tidak asing dengan peneliti. Dengan PENINGKATAN KETERAMPILAN MEMBACA INTENSIF DENGAN MENGGUNAKAN PEMBELAJARAN KOOPERATIF STRATEGI KWL PADA SISWA KELAS III SDN KALIWUNGU 1 KECAMATAN KALIWUNGU KABUPATEN SEMARANG 
keadaan seperti ini maka penelitian dapat berjalan dengan baik dan alami.

Pelaksanaan siklus meliputi dua hal yaitu, perencanaan umum dan perencanaan khusus. Yang dimaksud perencanaan umum adalah perencanaan yang meliputi keseluruhan aspek yang berhubungan dengan penelitian tindakan kelas. Sedangkan perencanaan khusus dimaksudkan untuk menyusun rancangan dari siklus per siklus. Perencanaan khusus terdiri atas perencanaan ulang atau disebut revisi perencanaan. Perencanaan ini berkaitan dengan penggunaan pendekatan pembelajaran, metode pembelajaran, dan lain sebagainya.

\section{HASIL PENELITIAN DAN PEMBAHASAN}

Pada siklus I ini dokumentasi foto yang diambil meliputi aktivitas siswa pada saat proses pembelajaran berlangsung seperti (1) saat guru menerangkan kegiatan pembelajaran yang akan dilakukan; (2) siswa membaca dalam hati teks bacaan; (3) siswa mengerjakan teks membaca intensif; (4) aktifitas siswa saat berdiskusi; (5) keseriusan siswa dalam mengerjakan soal individu. Diskripsi gambar pada siklus I selengkapnya dipaparkan berikut ini.

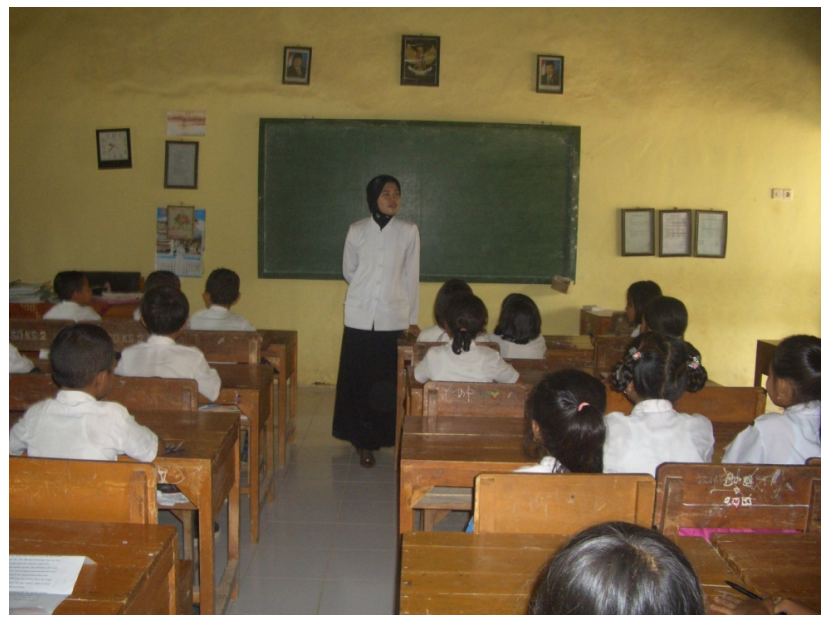

Gambar 2. Guru Menerangkan Kegiatan Pembelajaran

Gambar 2 di atas menunjukkan bahwa pada saat guru menerangkan pembelajaran yang akan dilakukan terlihat siswa-siswa memperhatikan dan begitu seksama memperhatikan penjelasan yang disampaikan oleh guru. 
p-ISSN : 1979-0414 e-ISSN : 2621-6256

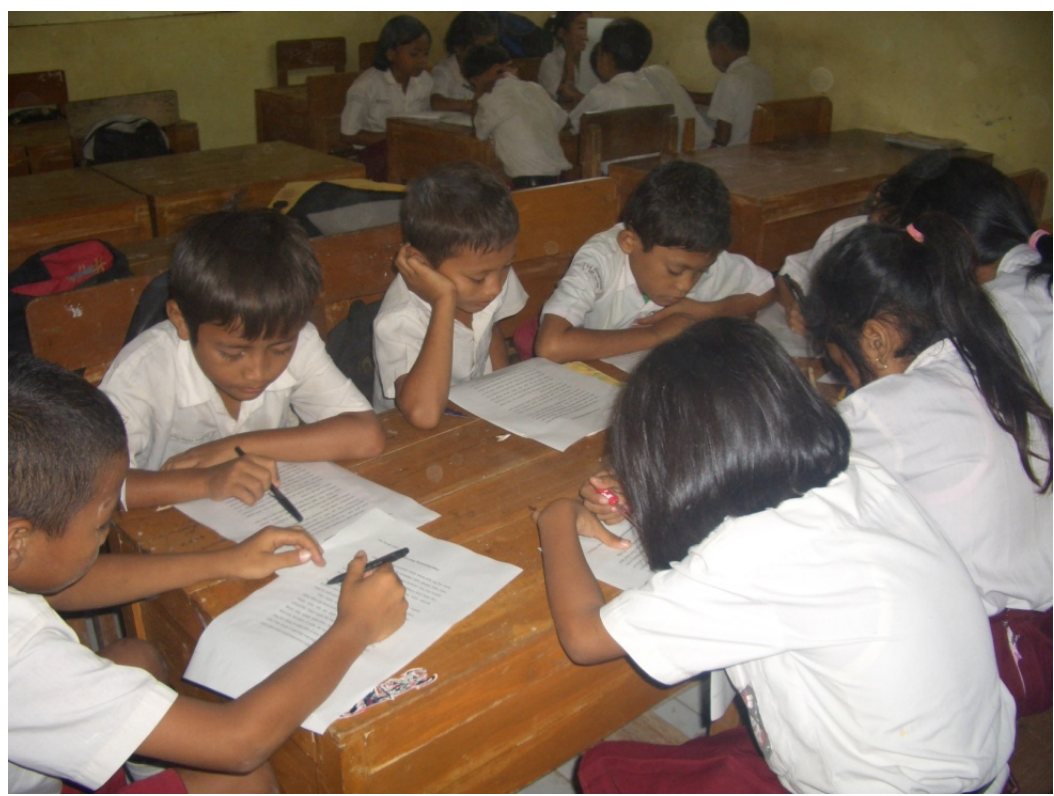

Gambar 3. Siswa Membaca dalam Hati Teks Bacaan

Gambar 3 di atas menunjukkan keseriusan siswa pada saat membaca teks bacaan pada saat berkelompok dan setiap anak mencatat hal-hal yang belum diketahui untuk ditanyakan kepada guru.

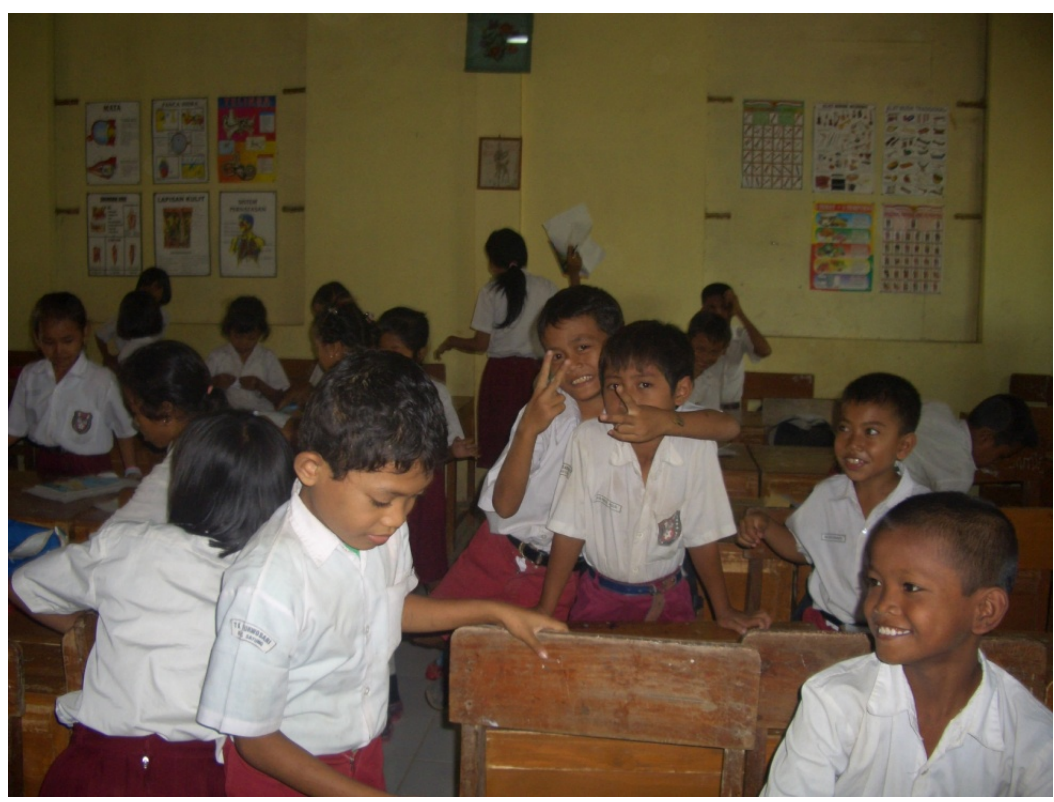

\section{Gambar 4. Aktivitas Siswa saat Membentuk Kelompok}

Pada gambar 4 di atas menggambarkan saat membentuk kelompok, banyak siswa yang hanya action di depan kamera dan senyam-senyum saat disuruh bergabung dengan kelompoknya. 


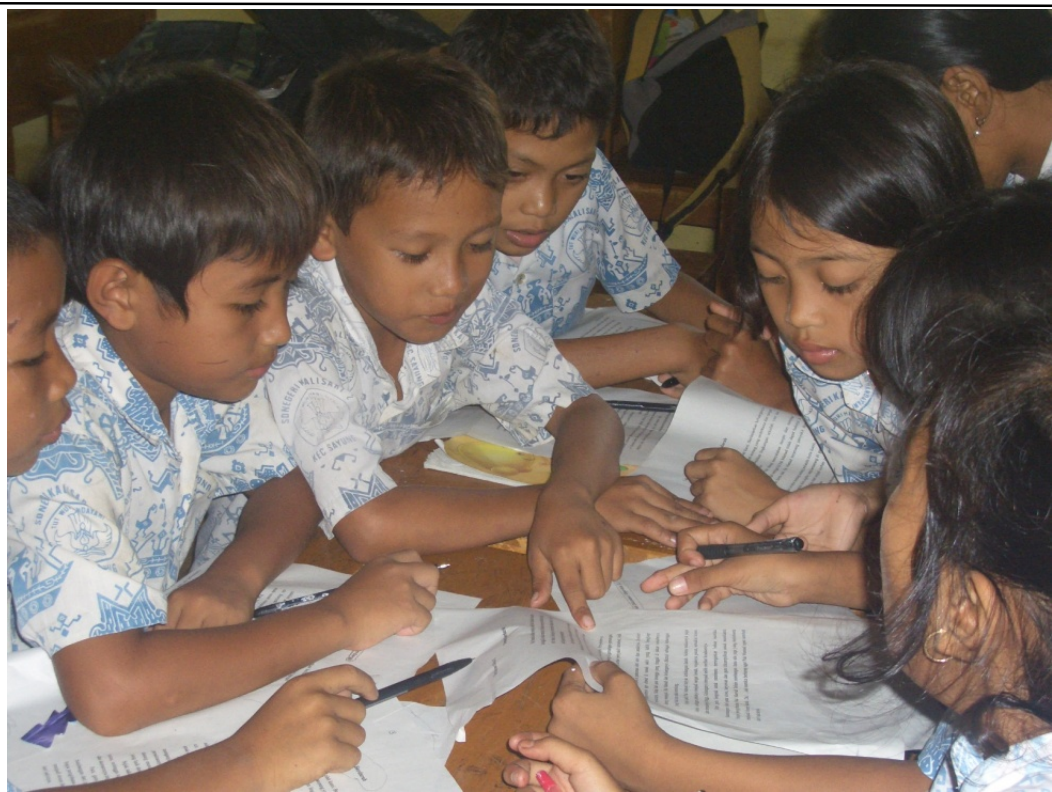

Gambar 5. Aktivitas Siswa pada saat Berdiskusi

Gambar 5 di atas menunjukkan keantusiasan siswa dalam mengikuti proses pembelajaran dengan berdiskusi. Dalam kegiatan berdiskusi siswa diharapkan menyumbang saran atau pendapat tentang bacaan yang sudah dibaca yang kemudian ditulis dilembar panduan strategi KWL yang sudah diberikan setiap masing-masing kelompok.

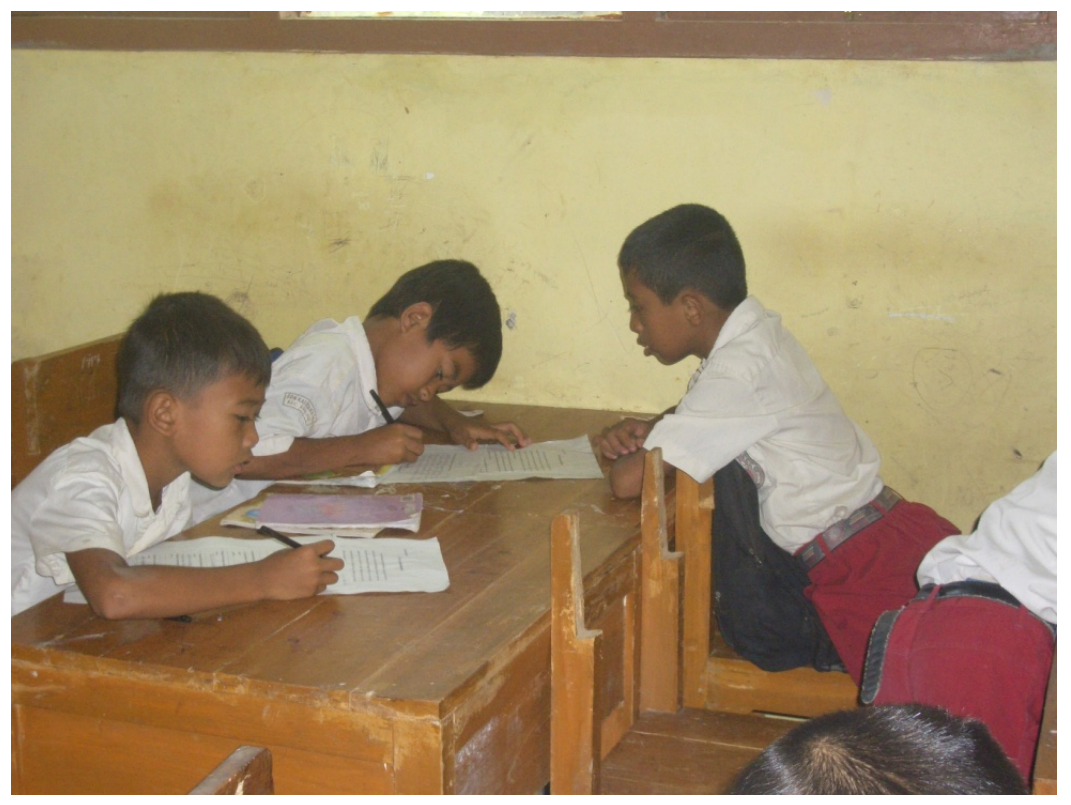

Gambar 6. Aktivitas Siswa pada saat Mengerjakan Soal Individu

Pada gambar 6 kita dapat melihat pada saat mengerjakan tes indivudu salah satu siswa menghadap ke belakang melihat pekerjaan temannya. Itu terbukti bahwa siswa masih belum serius ketika mengerjakan tes membaca intensif secara individu.

JURNAL ILMIAH KOMPUTER GRAFIS Vol. 14, No. 2, Desember 2021 : 138 - 147 
p-ISSN : 1979-0414 e-ISSN : 2621-6256

\section{KESIMPULAN DAN SARAN}

Adanya perubahan perilaku siswa kelas III SDN Kaliwungu setelah mengikuti pembelajaran membaca intensif dengan menggunakan stategi KWL. Perubahan-perubahan perilaku siswa ini dapat dibuktikan dari hasil data nontes yang meliputi observasi, wawancara, jurnal, dan dokumentasi. Sikap atau perilaku siswa mengalami perubahan dari perilaku yang negatif berubah menjadi positif. Kesiapan siswa untuk menerima pembelajaran ini mengalami peningkatan pada siklus II. Pada siklus I, siswa masih ada yang memperlihatkan perilaku negatif seperti berbicara dengan temannya tidak bersemangat saat pembelajaran, kurang bertanggungjawab dalam melaksanakan tugasnya, bermalas-malasan, merasa bosan, membuat kegaduhan, dan sebagainya. Pada siklus II, mereka sudah siap menerima pelajaran, bahkan siswa sudah aktif bertanya dan semakin bersemangat serta senang saat pembelajaran berlangsung. Selain itu, mereka terlihat antusias dan menikmati proses pembelajaran serta tugas-tugas yang diberikan dapat dikerjakan dan dilaksanakan dengan baik.

\section{DAFTAR PUSTAKA}

[1] Munawaroh. 2005. Peningkatan Kemampuan Membaca Intensif Teks Profil Tokoh dengan Pendekatan Kontekstual Komponen Inquiry pada Siswa Kelas VIIB SMPN 10 Semarang Tahun Ajaran 2005/2006. Skripsi Jurusan Bahasa dan Sastra Indonesia, Fakultas Bahasa dan Seni, Universitas Negeri Semarang.

[2] Roklimawati. 2007. Peningkatan Keterampilan Membaca Intensif dengan Pendekatan Kontekstual Komponen Inquiry pada Siswa Kelas VIIF SMPN 37 Semarang. Skripsi Jurusan Bahasa dan Sastra Indonesia, Fakultas Bahasa dan Seni, Universitas Negeri Semarang.

[3] Innasiah. 2005. Peningkatan Membaca Intensif Teks Berita dengan Pendekatan Kontekstual Komponen Inquiry pada Siswa kelas VIIE MTs. Negeri Salatiga Tahun Ajaran 2005/2006. Skripsi Jurusan Bahasa dan Sastra Indonesia, Fakultas Bahasa dan Seni, Universitas Negeri Semarang.

[4] Lestari, Yuliana Endar. 2007. Peningkatan Keterampilan Membaca Intensif Teks Berita dengan Strategi Metakognitif pada Siswa Kelas VIIC SMP Teuku Umar Semarang Tahun Ajaran 2006/2007. Skripsi Jurusan Bahasa dan Sastra Indonesia, Fakultas Bahasa dan Seni, Universitas Negeri Semarang.

[5] Pitayani. 2007. Peningkatan Keterampilan Membaca Intensif Grafik melalui Permainan Tim pada Siswa Kelas IXB MTs. Nurul Ulum Mranggen Demak Tahun Ajaran 2006/2007. Skripsi Jurusan Bahasa dan Sastra Indonesia, Fakultas Bahasa dan Seni, Universitas Negeri Semarang.

[6]Tarigan, Henry Guntur. 1987. Membaca Sebagai Suatu Keterampilan Berbahasa. Bandung : Angkasa.

[7] Rahim, Farida. 2005. Pengajaran Membaca di Sekolah Dasar. Jakarta : Bumi Aksara. 